\title{
Herbert Hill and the Federal Bureau of Investigation
}

Christopher Phelps

American and Canadian Studies, University of Nottingham, Nottingham, U.K.

christopher.phelps@nottingham.ac.uk

\begin{abstract}
This article points to previously undetected evidence demonstrating that Herbert Hill, labor director of the National Association for the Advancement of Colored People (NAACP) from the 1950s to the 1970s, informed for the Federal Bureau of Investigation (FBI) on his former political associates in the Socialist Workers Party (SWP). It shows that the FBI subsequently sought to use Hill in 1962 to obstruct a rumored fraternization between the NAACP and the Committee to Aid the Monroe Defendants (CAMD), an organization initiated by SWP members in support of the black militant advocate of armed self-defense Robert F. Williams and the movement he led in Monroe, North Carolina. The article concludes by posing a series of questions raised by the evidence and connecting the matter to recent scholarship on the Cold War and civil rights activism.
\end{abstract}

Keywords: Herbert Hill, NAACP, FBI, Robert F. Williams, SWP, socialism, radicalism, civil liberties 
At the height of the civil rights movement, the national labor secretary of the National Association for the Advancement of Colored People (NAACP) informed on radicals he knew in his youth to the Federal Bureau of Investigation (FBI), a connection never before detected. Herbert Hill (1924-2004), a prominent figure in the midcentury labor-liberal-civil rights coalition, is today remembered as either 'a major force in the effort to eliminate racial discrimination in the nation's labor unions,' or an irascible critic who lacked proportionality in his criticism of unions, or both things at once, depending upon one's point of view. To these divergent assessments it must now be added that Hill was an FBI informant. ${ }^{1}$

The pertinent documents, all from 1962, are publicly available on the FBI website, where Freedom of Information Act (FOIA) releases are digitally archived. ${ }^{2}$ The memoranda are concerned with efforts in New York City on behalf of civil rights activists in Monroe, North Carolina, led by Robert F. Williams, a militant advocate of armed self-defense. Bureau memos, part of the FBI's Counter-Intelligence Program (COINTELPRO) effort to disrupt solidarity with the militant Monroe movement, refer repeatedly to Hill supplying information on his former comrades in the Socialist Workers Party (SWP), to which he belonged in the 1940s. When responding to FOIA requests the FBI habitually redacts indicators that might betray informer identities, so Hill's name is blackened out. Sufficient indicators remain, however, to show that Hill provided information to the FBI while working for the NAACP, making him part of what David Garrow has called the 'truly huge foundation' of 'secret, cooperative human informants' that undergirded federal domestic surveillance during the Cold War. ${ }^{3}$

As NAACP labor secretary from 1951 to 1977, Hill was a fierce advocate of racial equality in America's unions and workplaces. He initiated NAACP lawsuits charging that major corporations such as General Electric, Shell Oil, and Lockheed as well as many labor 
unions, particularly in the building trades, had maintained exclusionary and discriminatory practices. Although Hill served as a link between industrial unionism and civil rights activism in the early 1950s, he later came to view most of organized labor, even such liberal redoubts as the International Ladies' Garment Workers Union and United Auto Workers, as bastions of institutional racism only superficially devoted to civil rights. While some saw principle in Hill's challenges to union inequities, others found the claims tendentious, put off by Hill's 'scathing and moralistic' prose style, as Eric Arnesen puts it. Hill saw seniority rights, considered sacrosanct by unions, as innately discriminatory against workers of color given a racially stratified U.S. job market and employment patterns in which blacks were last hired, first fired. He pursued federal decertification of unions found to have discriminatory records, a strategy controversial even among black trade unionists. He wrote prolifically on race and labor, especially for the socialist journal New Politics, often so astringently that even those who admired his pursuit of racial justice sometimes recoiled from its expression. His outspokenness was such that on many occasions he was presumed to be African American although he was Jewish. ${ }^{4}$

Evidence of Hill's cooperation with the Federal Bureau of Investigation is found in the Bureau's files on the Socialist Workers Party (SWP) and the Committee to Aid the Monroe Defendants (CAMD). The SWP, founded in 1938 by followers of Leon Trotsky, was by 1962 comprised mostly of a few hundred middle-aged veterans of the American labor left of the 1930s and 1940s. The SWP's activity revolved around the promotion of socialist ideas through a newspaper, publishing house, and public forums. Although the SWP was classed as subversive by the FBI and twenty-three of its leaders were imprisoned for violating the Smith Act in 1941, the SWP was never implicated in any act of violence or espionage. As for the CAMD, it originated in 1959, when two African-American boys, ages seven and eight, in Monroe, North Carolina, were removed from their homes and sentenced to reform school 
after being accused of a sexual offense for playing a benign kissing game with three white girls. The national NAACP shied away from defending the boys because of the case's 'sexual' aspect, prompting New Yorker George Weissman, an SWP member, to found the Committee to Combat Racial Injustice, which would morph into the CAMD. Robert F. Williams, the local Monroe NAACP chapter president, welcomed support from this 'small but energetic network of activists outside Monroe...poised to assist him on his own terms,' writes his biographer, Timothy B. Tyson. ${ }^{5}$

The story of Williams and the Monroe movement is a crucial factor in FBI interest in Herbert Hill. Born in Monroe, Williams moved to Detroit to work in auto plants during the Second World War, then served in the Army and Marine Corps, returning to his North Carolina birthplace in 1955. There he became an advocate of 'armed self-reliance' against white racist terror, facing down the Ku Klux Klan in a 1957 campaign to desegregate Monroe's swimming pools. In 1959, Williams's remark that the failure of the southern justice system would require blacks to 'meet violence with violence' made national news. The ensuing controversy prompted the NAACP to suspend Williams from his chapter presidency for half a year. In August 1961, seventeen Freedom Riders visited Monroe, hoping to illustrate to Williams the power of non-violence. They were met by a vigilante mob of thousands of white supremacists calling for death to 'niggers.' The resultant mêlée eventuated in the indictment of Williams by an all-white grand jury on a bizarre kidnapping charge. As Williams promptly went into hiding, a nationwide manhunt was ordered, as historian Raymond Arsenault writes, by 'J. Edgar Hoover, who firmly believed that Williams was part of a Communist-inspired plot to incite violence among disgruntled Southern blacks.' The dragnet failed to catch Williams. He had fled to New York where he was harbored by SWP members before fleeing to Canada, and then Cuba, where he lived for several years before travelling to Vietnam, China, and Tanzania. He returned to the U.S. in 1969, entering 
in Detroit. Fighting extradition to North Carolina until the much-transformed state dropped all charges against him in 1976, Williams lived in northern Michigan until his death in $1996 .^{6}$

Williams had already fled the country when, on May 10, 1962, the Special Agent in Charge (SAC) — or top officer—of the New York field office wrote to FBI Director J. Edgar Hoover, in Washington, D.C. The New York SAC expressed worry that the CAMD, which he termed 'an SWP civil rights front group,' might be on the verge of a partnership that would make it 'a 'legitimate' organization through support of the NAACP.' In reality such a convergence was exceedingly unlikely, but the FBI was keen to obstruct any liberal-radical rapprochement. 'It is believed,' wrote the SAC, 'that the leadership of the NAACP is probably unaware of the fact that the SWP created and runs the CAMD... It is felt that if the NAACP became aware of the control of the CAMD by the SWP, financial help and any other support would be withdrawn. It is felt that as a disruptive tactic, considerable damage could be done to the SWP by having the NAACP aware of the controlling influence over the CAMD.' To accomplish this, the New York SAC suggested the Bureau might make use of a person who belonged to 'the SWP in New York City during the approximate period of 19431949. ${ }^{7}$

That person was Herbert Hill. Born in 1924, Hill had joined the SWP while living in Manhattan as a teenager in the early years of the Second World War and left it in 1949, he said in an interview shortly before his death. After becoming involved in Harlem NAACP activism during the Second World War, he eventually left the SWP because of his increasingly negative view of Stalin's Soviet Union (which the SWP both criticized and partially defended as a 'degenerated workers' state') and his sense of 'the contrast between the NAACP engaging American society on the issue of race in a very forthright and direct way and the SWP stewing in its own juices year in and year out without having any impact on the real world.' Elsewhere in the FBI files, the informant is revealed to be male, and the 
blacked-out surname is short. The evidence most conclusively identifying Hill is found in documents passed between two high-level national FBI officials, William C. Sullivan, head of domestic intelligence, and F. J. Baumgardner, internal security section chief. Sullivan described the informant as an 'SWP member during the period 1943-1949, who is currently employed by the NAACP as a labor relations official.' Since the NAACP had no other labor official, let alone one who left the SWP in 1949, it is plain that the reference is to Hill. Geography, dates, party affiliation, sex, name length, employer, job title: All are a dead match. $^{8}$

The FBI initiated the contact, finding Hill obliging. Sullivan observed that the informant 'has [already] been contacted on several occasions by New York Agents and has been cooperative.' The New York SAC stated, 'He has been contacted on a few occasions by an Agent and has been cooperative in regard to furnishing information on individuals that were in the SWP during the time he was a member.' No details are provided of the conversations the FBI had with Hill, but perhaps the conversation was similar to an earlier conversation which occurred around 1941 when two agents approached Paul Jacobs, another former Trotskyist radical whose journalism highly critical of labor unions in the late 1950s led some to associate him with Hill. The FBI agents appeared on Jacobs's New York apartment doorstep shortly after he had ceased belonging to any socialist organization, asking him to testify against the SWP in the Smith Act case. Jacobs politely declined. 'They then suggested,' he recalled, 'without ever saying so specifically, that perhaps it might be advisable for me to cooperate with the government lest at some point in the future I, too, might find myself facing some kind of charge.' Unlike Jacobs, Hill opted to cooperate. The precise date of his first conversation with the FBI is unknown, but it apparently occurred after he began working for the NAACP in 1951. The FBI's perception was that Hill cooperated because he was concerned the NAACP would learn of his political past. As the SAC wrote to 
the Director, the informant 'has been continually anxious that his prior SWP connection not be revealed to any outside source and particularly to his present employers,' given that 'it is the policy of the NAACP to make every effort to keep itself free of any connection with a subversive organization in order that it may carry on its work more effectively., 9

No evidence exists that Hill informed on the members of the NAACP or any other civil rights or left-wing organization. Only the SWP is mentioned.

In 1962, the Bureau contacted Hill again, this time anonymously, in its effort to isolate the CAMD. Because of Hill's background, he was perceived as uniquely positioned at the NAACP to deflect reciprocity between it and the CAMD, for he wouldn't have any trouble connecting the dots to the SWP. Hill 'is probably not the individual who would make a decision on whether or not to support such an organization as CAMD,' noted the New York SAC, but 'he is highly enough placed to have the ear of such an individual. Furthermore, ...through his own personal experience [he] would be immediately aware of what the SWP was without any lengthy explanations being necessary.' Therefore, the New York SAC recommended that an anonymous telephone call be made to Hill stating 'the CAMD operated out of the second floor of 116 University Place, New York City [SWP headquarters], and that it was run on a day-to-day basis by...an SWP member,' whom other documents specify as Berta Green. Hill was to be 'told that it was felt he might be interested in passing this information on to appropriate leaders of the NAACP since it was understood that the NAACP had recently begun supporting the CAMD.' Sullivan supported the scheme. 'It is felt,' he wrote, 'that this operation should be approved since the possible withdrawal of NAACP support would have considerable disruptive effect upon the SWP and cause considerable damage to future SWP activities in the civil rights field. ${ }^{10}$

Having received authorization from the Director, the New York FBI reached Hill in an untraceable call at 4:15 p.m. on May 24,1962 . That the call was made anonymously 
would seem to indicate that Hill was not an operative taking conscious direction from the FBI and that the FBI did not wish to disclose to Hill the extent of its activities to isolate the CAMD, even if it viewed the information he supplied on his SWP contacts as useful, and even if it anticipated he would react negatively to SWP involvement. When the FBI's anonymous caller told Hill people associated with the CAMD were claiming to have obtained the endorsement and support of the NAACP, Hill 'denied vigorously that the NAACP had given any backing to the CAMD.' Although he 'made no statement as to any action he might take, it was noted that he was very forceful in his denial of NAACP connection with the CAMD and anxious to eliminate any impression the caller had that the NAACP would offer support in this instance.' With a typical COINTELPRO flourish, the FBI followed up by sending an anonymous letter from 'a true friend and supporter of Negro rights' which advised, 'It won't do the work of the NAACP in the South a bit of good if it's known its funds and good name are backing a group in the pocket of the SWP.'11

From the FBI's viewpoint, the result was a success. Four months later the New York SAC wrote to the Director to note that there was no longer any talk in SWP circles about NAACP friendliness toward the CAMD and that CAMD activities appeared to have lulled. 'It is believed quite possible,' stated the SAC, 'that calling attention of NAACP officials to control of CAMD by the SWP caused them to withdraw support which in turn lessened the value of this front to the SWP.'12

To summarize, FBI files indicate that Herbert Hill was a confidential informant for the Bureau, that he cooperated willingly and more than once regarding his former comrades in the SWP, and that the FBI sought to use him in 1962 to stymie possible fraternization between the CAMD and the NAACP. The latter episode provides a vivid example of the FBI's practice of sowing dissension in the civil rights movement, especially between black militants and moderates, a practice well-documented by scholars. ${ }^{13}$ That Hill informed for 
the FBI as NAACP labor director raises a number of new questions, both factual and moral, that may not be easily answered:

First, why did Hill consent to answer the government's questions about others? Numerous people in that period—not only Paul Jacobs but also playwright Arthur Miller and folksinger Pete Seeger, for example — declined to do so on the civil libertarian grounds that the state did not have the right to amass information on citizens engaged in political advocacy protected by the Bill of Rights. Did Hill cooperate because he saw no betrayal in sharing information about SWP members whose politics he no longer held? Or did he wish, as the FBI thought, to disguise his past from his employer? Or was the NAACP well aware of Hill's earlier radicalism when it hired him in 1951 and was he seeking to avoid public disclosure of that past in order not to expose the organization and himself to attack?

Was Hill, alternately, simply following standard NAACP practice? Walter White, Thurgood Marshall, and Roy Wilkins all assisted the FBI in its investigations of such radical organizations as the Communist-led Civil Rights Congress - both out of antipathy to the Communist Party and to protect the NAACP's legitimacy and ensure its survival in a period of political repression. ${ }^{14}$ Given the SWP's inclusion on the Attorney General's List of Subversive Organizations despite its longstanding criticism of the Communist Party and Stalinism, would NAACP officials have advised the same approach in regard to it?

Other questions will be unanswerable until there is full release of all twentieth-century FBI files, including those on informants, not merely subjects. When did Hill first inform? How often? Were his comments limited to those about SWP members or did he provide information about other radicals? Did his informing result in loss of employment or deportation for anyone? Given that Hill spent much of the 1940s participating in the SWP's Harlem branch, were some he identified African-American? 
Other questions concern Hill's legacy: Given the contested moral history of 'naming names,' should knowledge that Hill informed for the FBI alter our understanding of his place in civil rights or labor history_-and if so, how? In an admiring obituary, Stephen Steinberg stated: 'What fired up Hill's internal engines, what made him uniquely effective as labor director for the NAACP, was that he waged this struggle as a person of the left, committed to the ideals of socialism. ${ }^{15}$ Do such judgments require qualification given that Hill identified socialists to the FBI and informed about their backgrounds, surely knowing it might well jeopardize their livelihoods? Insofar as informing might invite easy condemnation, however, consider an obverse question: Would the NAACP have been as aggressive in challenging union and workplace racism in the civil rights era had Hill lost his position as labor secretary because of his leftist past? Was that — the instinct to stay alive to fight another day—what led Hill to comply with the FBI?

Such questions indicate the complications of midcentury moral and political life. They also connect to broader issues regarding the civil rights movement, the Cold War state, and the anti-Stalinist left. Hill's criticism of the Communist Party in the 1950s has been faulted as 'Stalinophobic' by historians Nancy Maclean and Alex Lichtenstein, with Lichtenstein suggesting a connection between Hill's anti-communism and Trotskyism. ${ }^{16}$ But given that Hill informed upon Trotskyists secretly while excoriating Communists publicly, is it not more likely that the form of his anti-communism of the 1950s and early 1960s reflected Cold War liberalism?

Finally, these FBI memos point to the paradox of the civil rights movement emerging out of a period of constriction upon civil liberties. What significance does the NAACP labor secretary's act of informing for the FBI hold in light of recent scholarship relating the civil rights movement to its Cold War setting? Does the FBI's attempted manipulation of Hill in its effort to keep the Monroe radicals estranged from the moderate civil rights leadership 
substantiate those who underscore Cold War ideology as inhibiting and dividing the black freedom movement—not merely a lever used advantageously? ${ }^{17}$ Despite the ineluctable differences between the ultimate aims of liberal integrationism, Marxism, and black nationalism, how often were openings for a modicum of mutuality between their adherents deflected by Cold War ideology or government intrusion? Is the 1962 episode of FBI political interference a case study in how Cold War anti-radicalism operated to decouple linkages of race and class that earlier activists had tried to forge? And does such a bifurcation of race from class ultimately explain the trajectory of Herbert Hill? 


\section{Bibliography}

Anderson, Carol. Eyes Off the Prize: The United Nations and the African American Struggle for Human Rights, 1944-1955. Cambridge: Cambridge University Press, 2003.

Arnesen, Eric. 'Assessing the Legacy of Herbert Hill,' Labor, vol. 3 (summer 2006): 12.

Arsenault, Raymond. Freedom Riders: 1961 and the Struggle for Racial Justice. Oxford: Oxford University Press, 2006.

Berg, Manfred. 'Black Civil Rights and Liberal Anticommunism: The NAACP in the Early Cold War,' Journal of American History (June 2007): 75-96.

Blackstock, Nelson. COINTELPRO: The FBI's Secret War on Political Freedom. New York: Vintage, 1976.

Carson, Clayborne, ed., Malcolm X: The FBI File. New York: Carroll and Graf, 1993.

David, James Kirkpatrick. There's Something Happening Here: The New Left, the Klan, and FBI

Counterintelligence. Berkeley: University of California, 2005.

Dudziak, Mary L. Cold War Civil Rights: Race and the Image of American Democracy. Princeton: Princeton University Press, 2000.

Federal Bureau of Investigation, Socialist Workers Party Records, 'The Vault,' http://vault.fbi.gov/cointelpro/socialist-workers-party/.

'Files Say Justice Marshall Aided FBI in 50's,' New York Times (4 Dec. 1996).

Final Report of the Select Committee to Study Governmental Operations with Respect to Intelligence Activities, Book III: Supplementary Detailed Staff Reports on Intelligence Activities and the Rights of Americans. Washington: U.S. Government Printing Office, 1976.

Garrow, David. 'FBI Political Harassment and FBI Historiography,' The Public Historian, vol. 10 (autumn 1988): 8 .

Garrow, David. The FBI and Martin Luther King, Jr. New York: W.W. Norton, 1981.

Greenberg, Jack. Crusaders in the Courts. New York: Basic Books, 1994.

Greenhouse, Steven. 'Herbert Hill, a Voice Against Discrimination, Dies at 80,' The New York Times (21 August 2004).

Halperin, Morton, Jerry Berman, Robert Borosage, and Christine Marwick. The Lawless State. New York: Penguin, 1976.

Harrington, Michael. Fragments of the Century. New York: Simon and Schuster, 1977.

'Herbert M. Hill, 1924-2004,' The Journal of Blacks in Higher Education, no. 46 (winter 2004-2005): 31.

Hill, Herbert. 'Black Protest and the Struggle for Union Democracy,' Issues in Industrial Society, vol. 1, no. 1 (1969): 19-29.

— . 'Black Protest, Union Democracy, \& AFT,' New Politics, vol. 8, no. 4 (fall 1970): 21-35.

— . 'The Communist Party_Enemy of Negro Equality,' The Crisis 58 (1951): 365-71, 421-24.

— . 'The ILGWU Today_The Decay of a Labor Union,' New Politics, vol. 1, no. 4 (summer 1962): 6-17.

—. Interview with author, Madison, Wisconsin, Oct. 21, 2001. 
— . 'Lichtenstein's Fictions Revisited,' New Politics, new series, vol. 7, no. 2 (winter 1999), 148-163.

— . 'Meany, Reuther, and the 1964 Civil Rights Act,' New Politics, new series, vol. 7, no. 1 (summer 1998): $82-107$.

— . 'Organized Labor and the Negro Wage Earner: Ritual and Reality,' New Politics, vol. 1, no. 2 (winter 1962): 7-19.

— . 'Race and the Steelworkers Union,' New Politics, new series, vol. 8, no. 4 (winter 2002): 174-207.

—. 'Race, Ethnicity, and Organized Labor: The Opposition to Affirmative Action,' New Politics, new series, vol. 1, no. 2 (winter 1987): 31-82.

Honey, Michael. Going Down Jericho Road: The Memphis Strike, Martin Luther King's Last Campaign. New York: Norton, 2008.

Jacobs, Paul. Is Curly Jewish? A Political Self-Portrait Illuminating Three Turbulent Decades of Social Revolt 1935-1965. New York: Atheneum, 1965.

Jonas, Gilbert. Freedom's Sword: The NAACP and the Struggle against Racism in America, 1909-1969. New York: Routledge, 2005.

Lichtenstein, Alex. 'Herbert Hill and the 'Negro Question,’' Labor (summer 2006): 33-39.

Lichtenstein, Nelson. 'Herbert Hill in History and Contention,' Labor (summer 2006): 25-31.

Lieberman, Robbie, and Clarence Lang, eds., Anticommunism and the African American Freedom Movement: Another Side of the Story. Hampshire: Palgrave McMillan, 2009.

Lynn, Conrad J. Monroe, North Carolina ...Turning Point in American History. Detroit: Correspondence, 1962.

Maclean, Nancy. 'Achieving the Promise of the Civil Rights Act: Herbert Hill and the NAACP's Fight for Jobs and Justice,' Labor (summer 2006): 13-19.

Marx, Gary T. ' Thoughts on a Neglected Category of Social Movement Participant: The Agent Provocateur and the Informant,' American Journal of Sociology 80 (Sept. 1974): 402-442

Nelson, Bruce. Divided We Stand: American Workers and the Struggle for Black Equality. Princeton: Princeton University Press, 2005.

O’Reilly, Kenneth. Racial Matters: The FBI's Secret File on Black America, 1960-1972. New York: Free Press, 1989.

Plummer, Brenda Gayle, ed. Window on Freedom: Race, Civil Rights, and Foreign Affairs, 1945-1988. Chapel Hill: University of North Carolina, 2003.

Record, Wilson. Race and Radicalism: The NAACP and the Communist Party in Conflict. Ithaca: Cornell University Press, 1964.

Schneir, Walter and Miriam. 'The Socialist Workers: Square Target of the FBI,' The Nation (25 Sept. 1976): 272-277.

Senate Committee on the Judiciary, Testimony of Robert F. Williams: Hearings, Parts 1-3, 91st Cong., 2nd. sess., 1971.

Stein, Judith. Running Steel, Running America: Race, Economic Policy, and the Decline of Liberalism. Chapel Hill: The University of North Carolina Press, 1998.

Steinberg, Stephen. 'Herbert Hill Remembered,' New Politics, no. 38 (winter 2005): 
Sullivan, Patricia. Lift Every Voice: The NAACP and the Making of the Civil Rights Movement. New York: New Press, 2009.

Tyson, Timothy B. Radio Free Dixie: Robert F. Williams and the Roots of Black Power. Chapel Hill: University of North Carolina Press, 1999.

Weissman, George. 'The Kissing Case,' The Nation (17 January 1959).

Williams, Juan. Thurgood Marshall: American Revolutionary. New York: Random House, 1999.

Williams, Robert F. Negroes with Guns. New York: Marzani and Munsell, 1962. 
1 'Herbert M. Hill, 1924-2004,' The Journal of Blacks in Higher Education, 31. The best overview is Lichtenstein, 'Herbert Hill in History.' Favorable treatments of Hill's NAACP tenure include Jonas, Freedom 's Sword, and Nelson, Divided We Stand; a critical appraisal is found in Stein, Running Steel, Running America.

${ }^{2}$ Specific documents will be cited, but all are found in Part 1 of 5 of the Socialist Workers Party records in 'The Vault' of the FBI: http://vault.fbi.gov/cointel-pro/socialist-workers-party/ .

${ }^{3}$ Garrow, 'FBI Political Harassment,' 8. See also Marx, 'Thoughts on a Neglected Category,' and 'The Use of Informants in FBI Domestic Intelligence Investigations,' Final Report of the Select Committee, 227-270.

${ }^{4}$ Greenhouse, 'Herbert Hill'; Arnesen, 'Assessing the Legacy,' 12. On Hill being mistaken as African American, see Harrington, Fragments of the Century, 97. For a sampling of Hill's many polemics for New Politics and other outlets, see the articles listed under his name in the bibliography.

${ }^{5}$ Tyson, Radio Free Dixie, 112.

${ }^{6}$ Arsenault, Freedom Riders, 412; Tyson, Radio Free Dixie, 112. On Williams and the Monroe movement, see: Weissman, 'The Kissing Case'; Lynn, Monroe, North Carolina ...; Williams, Negroes with Guns; Senate Committee on the Judiciary, Testimony of Robert F. Williams. On the FBI and the SWP, see Schneir, 'The Socialist Workers'; Blackstock, COINTELPRO; Final Report, op cit., 17-18, 361-364; and Halperin et al., The Lawless State, 90-134.

${ }^{7}$ SAC New York to Director, FBI, May 10, 1962.

${ }^{8}$ Hill interview; W. C. Sullivan to F. J. Baumgardner, May 14, 1962.

${ }^{9}$ W. C. Sullivan to F. J. Baumgardner, May 14, 1962; SAC New York to Director, FBI, May 10, 1962; Jacobs, Is Curly Jewish?, 111.

${ }^{10}$ SAC New York to Director, FBI, May 10, 1962; W. C. Sullivan to F. J. Baumgardner, May 14, 1962.

${ }^{11}$ SAC New York to Director, May 25, 1962.

${ }^{12}$ SAC New York to Director, Sept. 21, 1962.

${ }^{13}$ Carson, ed., Malcolm X; Honey, Going Down Jericho Road; David, There’s Something Happening Here; Garrow, The FBI and Martin Luther King, Jr.; Halperin et al., Lawless State, 61-89; O’Reilly, Racial Matters. 14 'Files Say Justice Marshall Aided FBI in 50’s,' New York Times; Williams, Thurgood Marshall; Greenberg, Crusaders in the Courts, 103-106; Jonas, Freedom's Sword, 148-149; Record, Race and Radicalism; Sullivan, Lift Every Voice, 370, 374-375; Garrow, 'FBI Political Harassment,' 12-13; Tyson, Radio Free Dixie, 155-156; 
Carol Anderson, 'Bleached Souls and Red Negroes: The NAACP and Black Communists in the Early Cold War, 1948-1952,' in Plummer, ed., Window on Freedom, 93- 114; and Berg, 'Black Civil Rights and Liberal Anticommunism.'

${ }^{15}$ Steinberg, 'Herbert Hill Remembered,' 115.

${ }^{16}$ Hill, 'The Communist Party'; Lichtenstein, 'Herbert Hill and the "Negro Question” '; Maclean, 'Achieving the Promise of the Civil Rights Act.'

${ }^{17}$ For the lever argument, see Dudziak, Cold War Civil Rights. For the hindrance argument, see Anderson, Eyes Off the Prize and Lieberman and Lang, eds., Anticommunism and the African American Freedom Movement. 